\title{
Colonial Preoccupations in Geoffrey of Monmouth's De gestis Britonum
}

\author{
Michael Faletra
}

Nearly three quarters of the way through the sweep of legendary history that constitutes Geoffrey of Monmouth's De gestis Britonum, the narrative grinds almost to a halt. Whereas parts of the history had glossed over dozens of kings and hundreds of years, sometimes in a page or two, the pace of events leading up to the reign of King Arthur had steadily slowed, only to arrive at a near standstill in Geoffrey's description of Arthur's Plenary Court. It is a moment of great political importance, the celebration of the king's victory both over the Saxons who had plagued the realm for a generation and over much of what is now France: like several of his more successful predecessors on the British throne, Arthur returns to Britain a conqueror. The Plenary Court held to stage Arthur's coronation and to celebrate his glorious new order takes place on Pentecost in the Welsh city of Caerleon: "Located in Glamorgan on the River Usk at a lovely site not far from where the Severn empties into the sea, it had an abundance of riches greater than that of any other city and was thus an

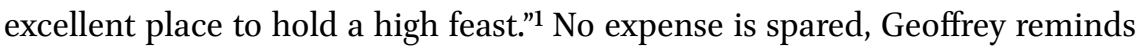
his Anglo-Norman readers, and he treats them to lavish descriptions of the coronation processions, the splendid regalia, the celebratory games, and the feasting for many hundreds of guests - all of which seem calculated to drive home the fact that ancient Britain had attained a cultural pinnacle: "Britain had at that point acquired such a state of dignity that it surpassed all other kingdoms in its courtliness, in the extravagance of its fineries, and in the polished manners of its citizens."2 In their enjoyment of the trappings of a cultural modernity characterized by courtly behavior and fine clothing (and later by Europe's first literary description of a tournament), the ancient Britons under King Arthur revel in a Caerleon that stands as the metropole of expansive

$1 \quad D G B$, ix.156.312-14: "In Glamorgantia etenim super Oscam fluuium non longe a Sabrino mari amoeno situ locata, prae ceteris ciuitatibus diuitiarum copiis abundans tantae sollempnitati apta erat." All translations are my own.

$2 D G B$, ix.157.385-87: "Ad tantum etenim statum dignitatis Britannia tunc reducta erat quod copia diuitiarum, luxu ornamentorum, facetia incolarum cetera regna excellebat." 
empire. The Arthurian moment is an imperial moment, and it reveals Geoffrey of Monmouth's preoccupation throughout his writings with the dynamics of colonization and conquest.

Among the many guests at this coronation are the subject-kings of Arthur's newly-won and far-flung empire: the kings of Iceland, Denmark, Norway, Gotland, and the Orkneys all pay their obeisance. But the most prominent under-kings are the ones who lead Arthur's coronation procession, namely the kings of Scotland, Moray, Cornwall, North Wales, and South Wales. The presence of these kings passes without comment, and Geoffrey tellingly never mentions Arthur as having subdued any of these areas. This silence, however, paradoxically reveals one of the most important of the ideological underpinnings of the $D G B$, a phenomenon that Simon Meecham-Jones calls the "discourse of Britishness", or what we might more broadly call the "myth" of Insular British unity, an idea that had assumed textual form as early as Gildas's 6th-century The Ruin of Britain. ${ }^{3}$ As Meecham-Jones sees it, "the discourse of Britishness proclaimed the 'natural' unity of the island(s) of Britain, inferring from physical continuity an inevitable political unity." ${ }^{3}$ The ready submission of the kings of Scotland, Wales, and Cornwall to King Arthur ratifies Meecham-Jones's insight, and it allows us to see more clearly that the concept of "Britain" itself is for Geoffrey hardly an apolitical one, suggesting that the island's various ethnic or political entities are rightly or naturally subordinated to a greater whole. The very concept of Britain being named after its single founder - the Trojan exile Brutus - reinforces the concept of a primal British unity, a unity standing in contrast to the more piecemeal ethnic, linguistic, and political subdivisions of the island in Geoffrey of Monmouth's own day.

Geoffrey's account of the initial division of the island into subsidiary realms brings to the fore some of the colonialist and imperialist impulses motivating his work. The second book of the $D G B$ opens with what almost amounts to a second origin myth, the partition of the island after the death of its first king, Brutus, among his three sons Locrinus, Albanactus, and Kamber:

Locrinus, the eldest, possessed that part of the island that was later called Loegria after him. Kamber received the area that lies beyond the River Severn and which is now called Wales, but which was called for a long time Kambria after him, which is why the people of that land who speak

3 See Gildas, The Ruin of Britain, ed. and trans. M. Winterbottom, Gildas: The Ruin of Britain and Other Works (Arthurian Period Sources, 7), Chichester, 1978.

4 S. Meecham-Jones, "Introduction", in R. Kennedy and S. Meecham-Jones (eds.), Authority and Subjugation in Writing of Medieval Wales, New York, 2008, pp. 1-11, at p. 2. 
the British tongue still call themselves the Cymry. And Albanactus, the youngest, ruled over that land which is now called Scotland but which he named Alban after himself. 5

Almost from its inception, then, the island of Britain fosters a plurality of realms, which Geoffrey frequently naturalizes through references to the rivers Humber and Severn as providing intuitive ways of subdividing the island. Yet two observations should be made about this second foundation myth. First, by its very references to dividing what was once whole - and by its showcasing the patrimony of Brutus, the eponymous founder himself - Geoffrey's account of the origins of Scotland, Wales, and Loegria (the area that his readers would easily recognize as "England") paradoxically reaffirms the preexistence and conceptual preeminence of the whole; England, Scotland, and Wales are inescapably, for Geoffrey, parts of a larger, geopolitically organic whole. Secondly, the story of the partition of the island among Brutus's three sons highlights the privilege given to the eldest. Locrinus receives what is geographically (and certainly economically) the lion's share of the island, the fertile lowlands of Loegria, which is also the site of most of the action of Geoffrey's history as a whole. In contrast, Kamber and Albanactus, the younger sons, receive the more peripheral portions of the realm. ${ }^{6}$ And while Albanactus, as Geoffrey relates, swiftly falls before incursions of Huns, thus delegitimizing from the outset the parity of Scotland with the other portions of Britain, Kamber assumes a quietly subordinate role to his brother Locrinus. It is, notably, the tale of Locrinus's descendants that Geoffrey follows through the $D G B$; the rulers of Wales - the petty kings of Demetia (Dyfed) and Venedotia (Gwynedd) who serve King Arthur at his Plenary Court - are in contrast a decidedly cadet branch of the royal line of Brutus.

Geoffrey's myth of this primitive (and distinctly hierarchical) partition of the island of Britain is not innocent of many of the power dynamics that animated the Anglo-Norman ruling classes in England during the 12th century. Monika Otter has written of the prevalence of the trope of gaainable tere - the idea of (new) territory that can be captured, settled, and cultivated - across a

$5 D G B$, ii.23.5-11: "Locrinus, qui primogenitus fuerat, possedit mediam partem insulae, quae postea de nomine suo appellata est Loegria; Kamber autem partem illam quae est ultra Sabrinum flumen, quae nunc Gualia uocatur, quae de nomine ipsius postmodum Kambria multo tempore dicta fuit, unde adhuc gens patriae lingua Britannica sese Kambro appellat; at Albanactus iunior possedit patriam quae lingua nostra his temporibus appellatur Scotia et nomen ei ex nomine suo Albania dedit."

6 For a fuller version of this argument, see M.A. Faletra, Wales and the Medieval Colonial Imagination: The Matters of Britain in the Twelfth Century, New York, 2014, pp. $28-36$. 
variety of Anglo-Latin and Anglo-Norman fictions in the mid-12th century, and she credits the inception of this trope to Geoffrey of Monmouth. ${ }^{7}$ In the generations following the Norman Conquest of England in 1066, Anglo-Norman elites engaged in a series of expansionist, essentially colonialist, campaigns that were both discursive and ideological and also sometimes openly employed diplomacy and military force in a bid to dominate the island of Britain beyond England itself. William the Conqueror, for instance, led an armed "pilgrimage" to St Davids in Wales in 1081, a harbinger of the Anglo-Norman Marcher barons who would follow in his wake, and both William Rufus and Henry I meddled seriously in Scottish politics. ${ }^{8}$ And all the Norman kings maintained a complicated arrangement of Marcher fiefdoms and colonies in Wales and along the ever-shifting Anglo-Welsh and Anglo-Scottish borders. Welsh poets and chroniclers felt the incipient loss of their lands most acutely. As the poet-priest Rhygyfarch ap Sulien puts it, "Now the labors of earlier days lie despised; the people and the priest are despised by word, heart, and work of the Normans. For they increase our taxes and burn our properties." ${ }^{9}$

With a perhaps very canny understanding of his Anglo-Norman audiences, Geoffrey of Monmouth constructs in his King Arthur not only an embodiment of some amalgam of "courtly" values, and not only a fitting representative of the restored unity of ancient Britain, but also a victorious conqueror. Arthur's coronation at Caerleon follows both his eradication of all the Saxon invaders and especially his conquest of Gaul. But just as the wheels of history might seem to slow to a halt at this moment, the action (and narrative pace) begins again with the arrival of an embassy of Romans to the newly-crowned Arthur's court. The Romans' haughty insistence that Britain pay its long overdue tribute is met with a swift military response from Arthur and his advisors, who mobilize the realm for war with Rome. Geoffrey thus supplies Anglo-Norman audiences with an eye to conquest and territorial expansion the greatest spectacle of all as he stages King Arthur's war upon - and decisive defeat of - the Roman empire. For later readers such as the 16th-century humanist Polydore Vergil,

7 M. Otter, Inventiones: Fiction and Referentiality in Twelfth-Century English Historical Writing, Chapel Hill, 1996, pp. 69-73, esp. p. 76.

8 For an authoritative examination of the Norman colonization of Wales, see R.R. Davies, The Age of Conquest: Wales, 1063-1415, Oxford, 2000; for a full discussion of Anglo-Norman policies concerning Scotland, see R. Bartlett, England Under the Norman and Angevin Kings, 10751225, Oxford, 2000, pp. 77-85.

9 Rhygyfarch ap Sulien, Planctus, ed. M. Lapidge, "The Welsh-Latin Poetry of Sulien's Family", Studia Celtica 8/9 (1973-74), 68-106, at pp. 90-91, 1l. 15-18: "Nunc dispecta iacent ardua quondam; / dispicitur populus atque sacerdos / uerbo, corde, opere Francigenarum, / namque tributa grauant, propria perurunt." 
Arthur's continental conquests were a little difficult to swallow, and Vergil takes advantage of their implausibility (including the absence of Arthur in any reliable corroborating sources) to unravel the entire skein of the Galfridian history of Britain. However, to judge by the enthusiasm with which Geoffrey's account of Arthur's conquests of Rome made it into the Anglo-Norman and Middle English chronicle and romance traditions, Geoffrey's English audiences seemed to have regarded this conquering Arthur with admiring eyes. (Even Malory's cycle of Arthurian romances, Le Morte D'Arthur, does not omit the Roman campaign). Despite Arthur's eventual fall at the hands of his nephew Mordred, the king long remained a vital repository of English imperialist ambitions.

Modern scholarship has on the whole remained agnostic about Geoffrey's intentions behind his expansionist, conquering King Arthur, a depiction not appearing in any of the text's known extant sources, although the epithet amherawdur, "emperor", appears in some of the early Welsh analogues. ${ }^{10}$ Robert Hanning considered Geoffrey's entire narrative, and King Arthur in particular, as a rather abstract meditation on the futility of the writing of history as a secular practice; Valerie Flint took this a step farther, in what remains perhaps one of the best pieces ever written on Geoffrey of Monmouth, arguing for the $D G B$ as a historiographic "parody" enabled by the author's status as a secular canon. ${ }^{11}$ For such critics, Arthur's continental conquests are not to be taken seriously: they either reveal the aimlessness of history or revel in that very aimlessness. Susan M. Shwartz, in contrast, reads Geoffrey's history of Arthur in a more Augustinian and penitential mode, seeing the king's failure to solidify his continental empire, and especially the poignant fact of his not being able to enter Rome itself, as a check on the very idea of imperial ambition. ${ }^{12}$

Against such claims that Arthur's continental exploits fuel an essentially anti-imperialist, anti-expansionist agenda, we might consider the campaign against Rome in tandem with some of the larger narrative patterns of the $D G B$. While Siân Echard has noted the tension between Arthur's apparent "superexcellence" and the fact that he is just one among a long, long series of Insular

10 P. Sims-Williams, "The Early Welsh Arthurian Poems", in R. Bromwich, A.O.H. Jarman, and B.F. Roberts (eds.), The Arthur of the Welsh: The Arthurian Legend in Medieval Welsh Literature (Arthurian Literature in the Middle Ages, 1), Cardiff, 1991, p. 48.

11 R.W. Hanning, The Vision of History in Early Britain: From Gildas to Geoffrey of Monmouth, New York, 1966, pp. 121-72; V.I.J. Flint, "The Historia Regum Britanniae of Geoffrey of Monmouth: Parody and Its Purpose. A Suggestion”, Speculum 54:3 (1979), 447-68.

12 S. Shwartz, "The Founding and Self-Betrayal of Britain: An Augustinian Approach to Geoffrey of Monmouth's Historia Regum Britanniae", Medievalia et Humanistica 10 (1981), $33-58$. 
monarchs, consideration of Arthur's conquests as themselves part of a long tradition - almost a royal prerogative of strong British kings - helps to resolve such ambiguities. ${ }^{13}$ As Arthur himself puts it:

For if [Rome] declares that tribute now be rendered merely because Julius Caesar and the other Roman rulers once subjugated Britain, then I believe that the Romans should now pay tribute to me, since my ancestors captured Rome in ancient times. The most noble Beli, with the aid of his brother Brennius, duke of the Allobroges, captured Rome and hanged twenty noble Romans in the middle of the Forum. He held the city for many years. And let us not forget Constantine, the son of Helen, or Maximianus, both my near kinsmen: they were both kings of Britain who also ascended to the throne of the Roman Empire. ${ }^{14}$

Arthur's references to the earlier kings here are far from coincidental. These kings were not only conquerors of Rome but also unifiers of the island of Britain, men who renewed the peace of the kingdom. Constantinus, for instance, "diminished the rapacity of thieves, trampled down the savagery of tyrants, and strove to restore peace everywhere". ${ }^{15}$ The reference to the story of Beli and Brennius is even more powerful. These two brothers had co-inherited the throne of Britain, which led to a bloody civil war. However, once they had made peace and united, they were able to conquer Rome itself. The historical episode thus serves as an object lesson: maintaining the integrity of the kingdom - that is, of the island of Britain as a cohesive geopolitical whole leads almost inexorably to the desire to expand its frontiers.

King Arthur as both a unifying force and as an index of expansionist power may have been a particularly poignant figure for Geoffrey's initial audiences. The England in which Geoffrey composed the $D G B$ in the years between 1136 and 1138 was a country riven by civil dissension. The death of Henry I and the

13 S. Echard, Arthurian Narrative in the Latin Tradition (Cambridge Studies in Medieval Literature, 36), Cambridge, 1998, p. 55 .

$14 D G B$, ix.159.466-74: "Nam si quia Iulius Caesar ceterique Romani reges Britanniam olim subiugauerunt uectigal nunc debere sibi ex illa reddi decernit, similiter ego censeo quod Roma michi tributum dare debet, quia antecessores mei eam antiquitus optinuerunt. Beli etenim, serenissimus ille rex Britonum, auxilio fratris sui usus, Brennii uidelicet ducis Allobrogum, suspensis in medio foro uiginti nobilioribus Romanis urbem ceperunt captamque multis temporibus possederunt. Constantinus etiam Helenae filius nec non Maximianus, uterque michi cognatione propinquus, alter post alterum diademate Britanniae insignitus, thronum Romani imperii adeptus est."

$15 D G B$, v.79.147-48: "Latronum rapacitatem hebetebat, tyrannorum saeuitiam conculcabat, pacem ubique renouare studebat." 
naming of his daughter Matilda as his heir, and the subsequent contestation of the throne by Henry's nephew Stephen, split the Anglo-Norman aristocracy and weakened the realm. At the same time, it also undercut efforts at expanding the territorial base of the Anglo-Norman barons beyond England proper. In particular, Anglo-Norman power in Wales was significantly checked. The years 1136-37 saw the commencement of what can only be called a native Welsh resurgence as Welsh chieftains captured or destroyed numerous English strongholds throughout their country. ${ }^{16}$ Indeed, the English would not regain control of many of these lost territories until the Edwardian conquest of Wales in the 128os. Certainly the events of 1136-37 more or less set the political map of Wales for the rest of the 12th century, and Geoffrey of Monmouth cannily recognized the ways in which the history he was in the process of composing might resonate with the new colonial situation. The figure of a triumphalist King Arthur who could unify the country, exert suzerainty over Wales and Scotland, and even extend British influence beyond its merely Insular sphere proved an invaluable imaginative touchstone for writers and readers throughout the 12th century and well beyond it. Certainly, as Amaury Chauou has argued, and as the manuscript tradition suggests, Geoffrey's model of an expansive Britain remained popular during the heyday of Henry II's "Angevin Empire." ${ }^{17}$

Nevertheless, many of the finer-grain political concerns of the $D G B$ have proven difficult for readers to detect, and Rees Davies has accused Geoffrey of being "a deliberate trader in multiple ambiguities". ${ }^{18}$ In terms of Geoffrey's interest in the intersection between the writing of history and the vexed issues of territorial acquisition both within and without Britain, Francis Ingledew probably best captures the critical ambivalence about the larger political and philosophical meanings of Geoffrey's project, writing that it is "especially astonishing" that Geoffrey should devise such an imperialist history for the ancient Britons. ${ }^{19}$ Ingledew here identifies a critical, and probably deliberate, confusion that Geoffrey perpetrates: the ancient Britons whose long history he narrates, whose kings he (more often than not) extols, and whose troubles he sometimes bewails - in short, the very Britons whose name is showcased in what Michael Reeve has now surmised was Geoffrey's original title for his

\footnotetext{
16 R.R. Davies, Age of Conquest, pp. 45-49.

17 A. Chauou, L'Idéologie Plantagenêt: Royauté arthurienne et monarchie politique dans l'espace Plantagenêt (XII ${ }^{e}-X I I I^{e}$ siècles), Rennes, 2001, pp. 37-39.

18 R.R. Davies, The Matter of Britain and the Matter of England: An Inaugural Lecture Delivered Before the University of Oxford on 29 February 1996, Oxford, 1996, p. 6.

19 F. Ingledew, "The Book of Troy and the Genealogical Construction of History: The Case of Geoffrey of Monmouth's Historia regum Britanniae", Speculum 69:3 (1994), 665-704, at p. 677 .
} 
work, the $D G B$ - are in many real ways continuous with, and identifiable with, the contemporary 12th-century Welsh. Geoffrey's book attempts to have it both ways: it offers praise for the glories of the ancient Britons while also emphasizing the degeneracy of their Welsh descendants from precisely that former glory.

Some earlier scholars, especially those whose focus was more on historiography than politics, saw little contradiction here. For Robert Hanning, "the 'meaning' of British history for Geoffrey ... is simply that Britain, like other nations, rises, flourishes, and falls." ${ }^{20}$ And "the Historia regum Britanniae", William Leckie writes, simply "chronicles the deeds of a flawed people, in whom the potential for greatness was matched and often surpassed by the capacity for folly". ${ }^{21}$ Still, there is little denying that the narrative arc of the $D G B$ concludes with a fairly unequivocal account of a translatio imperii, as the Saxons wrest control of the island from the native Britons, who subsequently are transformed into the first modern Welshmen:

Britain, having lost its entire population, except a few whom death had spared in the region of Wales, was hateful to the Britons for eleven years ... On receiving the news, that wicked people [the Saxons] assembled a vast crowd of men and women, landed in the region of Northumbria and filled the empty tracts of land from Scotland to Cornwall. There were no natives to stop them, save a few remaining Britons in the remote forests of Wales. This marked the end of British power in the island and the beginning of English rule. ${ }^{22}$

The English occupation of Britain is thus less a conquest than the resettlement of an uninhabited territory (itself a sort of fantasy of colonial acquisition that would survive well into the early modern colonization of the New World). The Britons, weakened at this stage by wars, plagues, famines, and internal dissension, do nothing to contest the claims of the new settlers. Geoffrey

$20 \quad$ Hanning, Vision, p. 171.

21 R.W. Leckie, Jr., The Passage of Dominion: Geoffrey of Monmouth and the Periodization of Insular History in the Twelfth Century, Toronto, 1981, p. 3.

$22 D G B$, xi.204.547-48, 53-58: "Britannia ergo, cunctis ciuibus, exceptis paucis quibus in Gualiarum partibus mors pepercerat, desolata, per .xi. annos Britonibus horrenda fuit.... Quod cum ipsis indicatum fuisset, nefandus populus ille, collecta innumerabili multitudine uirorum et mulierum, applicuit in partibus Northamhimbriae et desolatas prouincias ab Albania usque ad Cornubiam inhabitauit. Non enim habitator qui prohiberet praeter pauperculas Britonum reliquias quae superfuerant, quae infra abdita nemorum in Gualiis commanebant. Ab illo tempore potestas Britonum in insula cessauit et Angli regnare coeperunt." 
reinforces the justness of the advent of the Saxons - an act that amounts, essentially, to the legitimation of the transformation of British "Loegria" into Saxon "England" - by also suggesting that the concurrent transformation of the remaining Britons into the Welsh marks a descent into barbarity: "Resolute in their barbarous ways, they were no longer called Britons, but Welsh, a term derived either from their leader Gualo, or from queen Galaes or else from their very barbarity."23 Geoffrey adds that these barbarous Welsh-Britons foolishly engaged in foreign wars and civil strife, further hamstringing any attempts at future resurgence.

Geoffrey's fairly undiluted emphasis on Welsh barbarity on the closing page of the $D G B$ might imply, as a point of contrast, a strong sense of English/ Anglo-Norman cultural superiority, thus suggesting possible cultural justifications for the annexation of Welsh territories. Nonetheless, critical understandings of Geoffrey's precise political message have been quite diverse, with views ranging from seeing Geoffrey as a ruthless apologist for Anglo-Norman hegemony in Wales to Geoffrey as a proponent of Welsh proto-nationalism or as a postcolonial subaltern speaking back to empire. Many scholars in the earlier part of the 2oth century, in fact, tended to view Geoffrey fairly unproblematically as a Welshman, taking his toponymic "of Monmouth" as an index of ethnic origin and thus ethnic loyalty; this opinion still occasionally garners modern proponents. ${ }^{24}$ Under such an understanding, Geoffrey's narration of the (mostly glorious) deeds of the ancient Britons was seen as a way in which the historian celebrated his own ancestry, for the benefit of Latin-speaking audiences in his homeland and beyond. J.S.P. Tatlock's landmark 1950 volume The Legendary History of Britain endorsed a rather different paradigm, one first proposed by J.E. Lloyd in 1911 and one that opened up ways of making sense of Geoffrey's well-documented sense of ambiguity. ${ }^{25}$ Tatlock, following Lloyd, conjectured that either Geoffrey or one of his immediate ancestors was among the contingent of continental Bretons who had occupied Monmouth in the wake of the Norman Conquest, quite possibly a relative of the Breton baron Wihenoc, an early Norman lord of Monmouth. ${ }^{26}$ The Breton solution - which

$23 D G B$, xi.207.592-94: "Barbarie etiam irrepente, iam non uocabantur Britones sed Gualenses, uocabulum siue a Gualone duce eorum siue a Galaes regina siue a barbarie trahentes."

24 See, for instance, B.F. Roberts, "Geoffrey of Monmouth and Welsh Historical Tradition", Nottingham Mediaeval Studies 20 (1976), 29-40; and, most recently, K. Jankulak, Geoffrey of Monmouth, Cardiff, 2010, pp. 3-4.

25 J.E. Lloyd, A History of Wales from the Earliest Times to the Edwardian Conquest, 2nd ed., London, 1912, pp. 523-24; id. "Geoffrey of Monmouth", EHR 57 (1942), 46o-68, at pp. 467-68.

Tatlock, $L H B$, pp. $440-43$. 
is, incidentally, still a tenable position - has the advantage of making sense out of what is, for some, Geoffrey's otherwise rather inexplicable denigration of the Welsh Britons. For Geoffrey, Tatlock suggests, the Bretons of northwestern Gaul were the only legitimate descendants of the ancient Britons, and so the account of the degeneration of the Welsh at the end of the history is concomitantly an affirmation of Breton legitimacy. ${ }^{27}$ The supposition that Geoffrey was of Breton extraction also allows one to make sense of the curiously positive role played by Brittany throughout the $D G B$, and, in a broader way, it enables readers to come to terms with some of Geoffrey's more ambivalent attitudes toward the Britons in general. It was on this basis that John Gillingham argued for a Geoffrey of Monmouth who, as a fellow Cambro-Norman, appreciated the noble ancestry of the Welsh and could thus compose the $D G B$ as a piece of propaganda to encourage his Anglo-Norman patrons to enlist Welsh aid during the English civil wars of the 113os and 1140s. ${ }^{28}$

In the wake of the fuller understanding of the manuscript and textual traditions behind the $D G B$ provided by the prodigious work of Neil Wright and Julia Crick in the 1980s and 199os and culminating in the Michael Reeve and Neil Wright edition of 2007, more recent scholars have been inclined to emphasize the importance of Geoffrey of Monmouth's ties to his English patrons, regardless of his ethnic origins. ${ }^{29}$ Geoffrey was, to be sure, a protégé of Bishop Alexander of Lincoln; he was a secular canon at St George's collegiate church in Oxford (which received royal patronage), and seems to have been closely associated with several of the major players in the civil wars, even standing as a witness to the historic Treaty of Westminster in 1153. His appointment to the vacant bishopric of St Asaph in North Wales in 1152, a post he never occupied

27 Tatlock, $L H B$, pp. 396-402.

28 J. Gillingham, "The Context and Purposes of Geoffrey of Monmouth's History of the Kings of Britain", Anglo-Norman Studies 13 (1990), 99-118 (repr. in id. (ed.), The English in the Twelfth Century: Imperialism, National Identity and Political Values, Woodbridge, 2ooo, 19-39).

29 See, for example, K. Robertson, "Geoffrey of Monmouth and the Translation of Insular Historiography”, Arthuriana 8:4 (1998), 42-57; Otter, Inventiones; Echard, Arthurian Narrative; J. Blacker, The Faces of Time: Portrayal of the Past in Old French and Latin Historical Narrative of the Anglo-Norman Regnum, Austin, 1994; M.A. Faletra, "Narrating the Matter of Britain: Geoffrey of Monmouth and the Norman Colonization of Wales", The Chaucer Review 35:1 (2000), 60-85; P.C. Ingham, Sovereign Fantasies: Arthurian Romance and the Making of Britain, Philadelphia, 2001, pp. 21-5०; P. Dalton, "The Topical Concerns of Geoffrey of Monmouth's Historia Regum Britannie: History, Prophecy, Peacemaking, and English Identity in the Twelfth Century", Journal of British Studies 44:4 (2005), 688-712; and F. Tolhurst, Geoffrey of Monmouth and the Feminist Origins of the Arthurian Legend, New York, 2012. 
due to Welsh unrest in the region, is a further sign of his implication within Anglo-Norman elite power structures. Should he have taken up his seat at St Asaph, Geoffrey - whatever his ultimate political loyalties - would have had to acknowledge both the king of England and the archbishop of Canterbury as his functional overlords and would have surely been in the position of having to facilitate, or at least not actively resist, English colonial expansion into northern Wales.

Michelle Warren, perhaps seeing speculation about Geoffrey's political and/ or ethnic loyalties as fruitless, applies the lens of postcolonial literary theory to bear on the historian, painting a convincing picture of Geoffrey as a "border writer" whose upbringing in Monmouth and whose learned perspectives would have encompassed both Welsh and English modes of perceiving and inflecting power. ${ }^{30}$ What earlier scholars such as Valerie Flint or John Gillingham might view as Geoffrey's wry ambiguity or studied ambivalence Warren views as a series of "subtle negotiations" of power: "By alternately claiming and disavowing his textual authority Geoffrey unsettles paradigms of domination."31 As a result, Warren writes, the $D G B$ "thus equivocates between admiration and condemnation of conquering history; it mediates between colonial and postcolonial imaginations". ${ }^{32}$ In a similar vein, and through a similar application of postcolonial theory, Jeffrey Jerome Cohen sees Geoffrey as offering "an alternative account of Britain that could challenge the Anglo-centric version originated by Bede and reinvigorated by William [of Malmesbury]". ${ }^{33}$ While such perspectives built upon postcolonial cultural theory certainly help to make sense of the many contradictions and often frustrating ambiguities of Geoffrey's work, and while they also draw many fruitful parallels with many more recent contestations of colonial power in the 19th and 2oth centuries, the reader must tread carefully in applying postcolonial critiques unreflectively or ahistorically. As any student of literature understands, the assignment of intention to an author (or "meaning" to a text) is no easy matter and necessarily rests upon detailed and historicized understanding of the background, narrative structures, and systems of imagery of a given text.

Geoffrey, for his part, was happy to defer questions about the ultimate meaning of his text to his putative source, "a certain very ancient book in the

30 M.R. Warren, History on the Edge: Excalibur and the Borders of Britain, 1100-1300 (Medieval Cultures, 22), Minneapolis, 2000, pp. 25-59.

31 Warren, History on the Edge, p. 27.

32 Warren, History on the Edge, p. 25.

33 J.J. Cohen, Hybridity, Identity, and Monstrosity in Medieval Britain: On Difficult Middles, New York, 2006, p. 7 . 
British tongue". ${ }^{34}$ Naturally, the precise identity, qualities, and content of this ancient book - if it even ever existed, which it likely never did - have been the subject of considerable critical scrutiny and have had an important bearing on questions about Geoffrey's political alignment and especially his attitudes regarding English colonialism in Wales. In general, the assumption that Geoffrey was indeed working with a legitimate source in the British language correlates with the notion that his attitudes toward Wales and the Welsh were largely sympathetic: he can thus be taken at face value as wishing to resuscitate for modern audiences the (mostly) glorious deeds of the ancient British kings, and perhaps especially of King Arthur. ${ }^{35}$ And certainly some earlier scholarship viewed Geoffrey and his source in this light. Acton Griscom's magisterial 1929 edition of the $D G B$ was so confident of Geoffrey's reliance on a genuine Welsh source (or perhaps an amalgam of various "British" sources) that he printed a later Welsh translation of the text beneath his edited Latin version. ${ }^{36}$ Griscom's underlying assumption is that Geoffrey's text, being the real translation of an actual British or Welsh history, represents a legitimate and broadly accurate account of the pre-Saxon Insular past.

Conversely, skepticism about Geoffrey's claims to be translating an actual British book given to him by Walter, the archdeacon of Oxford, often correlates with a skepticism about the historian's Welsh sympathies and with an understanding of him as a sophisticated, canny, and maybe even playful ally of the English intelligentsia. Certainly whatever patchwork of sources that Geoffrey cobbled together included Welsh materials, as Ben Guy argues in this volume, and probably also sources in Cornish and even Breton, but the idea that the "very ancient book in the British tongue" ever existed as an integral whole seems difficult to maintain, thus weakening the claims that Geoffrey, in transmitting the deeds of the British kings to future generations, was thereby necessarily advancing the cause of Welsh proto-national sovereignty.

Viewing Geoffrey of Monmouth as a fabricator rather than a faithful copyist of the history he narrates allows one to perceive more clearly some of the power dynamics underlying the work as a whole. Monika Otter perhaps puts

$34 D G B$, Prologus 2.10: "quendam ... Britannici sermonis librum uetustissimum".

35 This is how one might regard Geoffrey's desire to "set out in excellent style a continuous narrative of all their [the kings'] deeds", "actus omnium [regum] continue et ex ordine perpulcris orationibus proponebat", $D G B$, Prologus 2.11-12 (trans. Wright). And see Gillingham, "Context and Purposes", p. 100.

36 See Geoffrey of Monmouth, De gestis Britonum, ed. A. Griscom, The Historia Regum Britanniae of Geoffrey of Monmouth with Contributions to the Study of its Place in early British History with a Literal Translation of the Welsh Manuscript No. LXI of Jesus College Oxford, London, 1929. 
it best when she claims that "[t]he historian is a pioneer, but the land is not entirely pristine; appropriating a space of one's own involves both exploitation and denial of what came before." ${ }^{37}$ Otter shrewdly observes that every act of writing history is necessarily a sort of colonization, an imposition of ideas of causation, of points of thematic emphasis, and of narrative structures upon the past. And certainly, one of Geoffrey's most evident and consistent narrative interests lies in the theme of translatio imperii or what Leckie has called "the passage of dominion". ${ }^{38}$ An examination of the ways in which sovereignty over the island of Britain changes hands throughout the $D G B$ allows one to better gauge the vexed assessment of the history as a colonial or even a postcolonial text. Through his creation of a new myth of British origins, through his strategic use of prophecies - especially the prophecies of Merlin - and through his narration of the "end" of Insular British history, Geoffrey reveals the contours of his thought about the status of Wales and the Welsh and about the persistent Anglo-Norman colonial interest in Wales in particular and throughout Britain as a whole.

Geoffrey in fact seems preoccupied with the interrelated ideas of conquest, colonization, and settlement. Indeed, "pre-occupation" may be the operative term here, as his foundation myth for the island of Britain demonstrates. On the face of it, Geoffrey's account of the foundation of Britain is hardly surprising. Like many historians throughout the Middle Ages, Geoffrey traces the origins of the ancient Britons to Troy, the great city of Homeric and Virgilian epic whose "fortunate fall" spawned foundation legends for many a medieval polity. As Ingledew points out, the myth of Trojan origin provided nascent medieval states with a secular origin story that could stand in contrast to the more Augustinian historiographies of the earlier Middle Ages. ${ }^{39}$ In the case of the $D G B$, Geoffrey found a ready-made tale in (pseudo-)Nennius's 9th-century Historia Brittonum. For Nennius and Geoffrey both, Britain was founded by Brutus (the name is Britto in the earlier text), a descendant of Aeneas and thus a member of the same Trojan family that had founded Rome. Exiled from Italy because of accidental parricide, Brutus eventually makes his way to the isle of Albion, which he renames Britain after himself. The Nennian account rounds the story off neatly, stating merely that "[Britto] came afterward to this island, which is named after him - that is, Britain - and he populated it with his kindred and dwelt there. Thus Britain has been inhabited from that very

37 Otter, Inventiones, p. 83 .

38 Leckie, Passage of Dominion.

39 Ingledew, "Book of Troy", p. 671. 
day until this very day." ${ }^{\text {40 }}$ Geoffrey later reinforces this myth of Trojan origins by noting that the ancient, original name of London was Trinovantum (derived from Troia Nova: "New Troy") and that, many centuries later, in the days of King Arthur, certain Trojan courtly customs were still maintained..$^{41}$ The link to Troy remained for Geoffrey a vibrant thematic thread throughout his history. ${ }^{42}$

Although his Nennian source thus provides a simple and solid outline of the foundation, naming, and initial populating of Britain, Geoffrey adds considerable complications to the story as he adapts it in the $D G B$. In Geoffrey's version, the land in which Brutus and his band of Trojan exiles arrive is, unexpectedly and unmistakably, already inhabited:

In those days, the island was called Albion, and was uninhabited except for a few giants. It was a beautiful place, filled with forests and with rivers that teemed with fish. It inspired Brutus and his companions with a great desire to settle there. As they explored the various regions of the island, the Trojans discovered giants who had fled to caves in the mountains. With the approval of their leader, the Trojans then partitioned the land among themselves and began to cultivate the fields and construct buildings so that, after a short space of time, you would think that they had lived there forever. ${ }^{43}$

On the one hand, Geoffrey deftly relegates his mention of the giants here almost to an aside in the narrative, a historical footnote. But in a larger sense, the vestigial presence of even "a few giants" seriously undermines the idea of a pristine Britain, ripe for colonization, calling into question the very force of the idea of foundation. The text's juxtaposing of the presence of these few giants with the mention of the island's original name of Albion (a name absent in the Nennian account) suggests a longer, earlier, and unexplored past looming - if

$40 \quad$ Historia Brittonum, ed. and trans. J. Morris, Nennius: British History and the Welsh Annals (Arthurian Period Sources, 8), London, 1980, p. 6o: "postea ad istam pervenit insulam, quae a nomine suo accepit nomen, id est Brittanniam, et inplevit eam cum suo genere, et habitavit ibi. Ab illo autem die habitat est Brittannia usque in hodiernum diem."

$41 \quad D G B$, ix.157.375-77.

42 On this topic, see esp. Ingledew, "Book of Troy"; and S. Federico, New Troy: Fantasies of Empire in the Late Middle Ages, Minneapolis, 2003, pp. ix-xxiv.

$43 D G B$, i.21.453-59: "Erat tunc nomen insulae Albion; quae a nemine, exceptis paucis gigantibus, inhabitabatur. Amoeno tamen situ locorum et copia piscosorum fluminum nemoribusque praeelecta, affectum habitandi Bruto sociisque inferebat. Peragratis ergo quibusque prouinciis, repertos gigantes ad cauernas montium fugant, patriam donante duce sorciuntur, agros incipiunt colere, domos aedificare, ita ut in breui tempore terram ab aeuo inhabitatam censeres." 
only fleetingly - before the reader: Was Albion the giants' name for their own land? Were they autochthonous? How long had they lived there, and in what numbers? How did it come about that their numbers had now so drastically dwindled? One might say that the presence of the giants in fact haunts the entire subsequent description of the Trojan's initial exploration and cultivation of Britain.

Geoffrey's Britain is thus always already inhabited. For Jeffrey Jerome Cohen, the presence of the giants is an example of what he calls extimité, a figure for the excess of the Lacanian Real that surpasses any narrative, logical, or ideological attempts to impose authoritative orders on the world. ${ }^{44}$ While Cohen admits that "Geoffrey of Monmouth is the true father of 'Britain' as an imagined community", he also emphasizes that the presence of the aboriginal giants is a function of the violence of foundation (and, implicitly, colonization), a reminder that the repressed will return..$^{45}$ And return they do. Not long after the Trojans solidify their initial settlements, they are faced with an uprising of Albion's gigantic aboriginals:

There was among them a certain loathsome one named Goemagog who stood some twelve cubits tall. This Goemagog was so strong that he once uprooted an oak tree as if it were a hazel-shoot. One day, when Brutus was celebrating a feast to the gods at the place where the Trojans had first landed, Goemagog came with twenty other giants and caused great slaughter among the Britons. ${ }^{46}$

Although the band of giants is summarily dispatched, they nonetheless leave an indelible trace on the otherwise pristine British topography. Goemagog himself meets his death by being wrestled to the death by Brutus's Herculean wingman, Corineus, and is cast off a precipice which, Geoffrey notes, bears his name "up to the present day". ${ }^{47}$ The giant himself is literally expelled from the landmass of Britain, but his name remains. And lurking behind his name lie the enigmatic, biblical Gog and Magog, a confederacy of Japethic tribes

44 J.J. Cohen, Of Giants: Sex, Monsters, and the Middle Ages (Medieval Cultures, 17), Minneapolis, 1999, pp. xii-xiii.

45 Cohen, Of Giants, p. 40; see also Cohen's seminal essay "Monster Culture: Seven Theses", in id. (ed.), Monster Theory: Reading Culture, Minneapolis, 1996, pp. 3-25, esp. pp. 4-7.

$46 \quad D G B$, i.21.469-74: "Erat ibi inter ceteros detestabilis quidam nomine Goemagog, staturae duodecim cubitorum, qui tantae uirtutis existens quercum semel excussam uelut uirgulam corili euellebat. Hic quadam die, dum Brutus in portu quo applicuerat festiuum diem deis celebraret, superuenit cum uiginti gigantibus atque dirissima caede Britones affecit." $D G B$, i.21.487-89: "usque in praesentem diem". 
inimical to God's Chosen People whose return, as Geoffrey knew well from the biblical books of Ezekiel and Revelation, was an omen of the end of the world. ${ }^{48}$

Geoffrey's devising of Goemagog's name, then, was hardly accidental: he well understood the power of apocalyptic imagery to unsettle the reader and to lend an episode a sense of historic import. Nowhere is this so evident than in his presentation of the prophecies of Merlin, which, because they stand almost as a metatext that comments on the unfolding of British history as a whole, have a significant bearing on our understanding of Geoffrey's colonial preoccupations. ${ }^{49}$ The $P M$ originally circulated independently, and Geoffrey's composition of it around the year 1135 earned him some small literary fame even before the completion of the $D G B$ a few years later; around 115 o he revisited the genre of Merlinic prophecy with a new book, the $V M$, which would feature an extended dialogue between Merlin and the legendary Welsh figure of Taliesin. ${ }^{50}$ As it stands integrated into the larger history, Geoffrey's rendition of the prophetic utterances of the boy-prophet Merlin to King Vortigern function, as Michael Curley has argued, as a sort of pivot point in the text: located at almost the center of the narrative of the $D G B$, the prophecies provide a symbolic counterpoint to the text's introduction of the Saxons, who figure both as the villainous allies of the nefarious Vortigern and as a foreign people who threaten to precipitate a new passage of dominion (translatio imperii) upon the island of Britain. ${ }^{51}$ The prophecies are thus hardly innocent of the dynamics of power and a concern with the relationships between the ancient Britons and later colonists of the island.

The core of Geoffrey's $P M$ derives from an episode in the Historia Brittonum, where the boy-prophet Ambrosius, gifted with uncanny powers, explains to Vortigern why the tower he had been attempting to build keeps collapsing. The Historia Brittonum's Ambrosius (and later the $D G B$ 's Merlin) instructs the king to excavate beneath the foundations of the tower, an action that reveals and releases two "dragons" (vermes in the Historia Brittonum, dracones in the DGB), one red and one white. The initial interpretation that Geoffrey's Merlin offers of this strange omen is fairly straightforward:

\footnotetext{
48 See Ezekiel $38-39$ and Revelation 20:7-10.

49 For a full discussion of the $P M$, see especially Maud Burnett McInerney's contribution to the present volume.

$50 \quad$ M.J. Curley, Geoffrey of Monmouth (Twayne's English Authors Series, 509), New York, 1994, pp. 48-49. For a more general overview of the dynamics of the Merlinic prophecies in Geoffrey's work, see J. Crick, "Geoffrey of Monmouth, Prophecy and History", Journal of Medieval History 18:4 (1992), 357-71. And see VM.

51 Curley, Geoffrey of Monmouth, p. 48.
} 
Woe to the Red Dragon, for its end hastens! The White Dragon, which refers to the Saxons whom you have invited here, will occupy its caves. The Red Dragon stands for the people of Britain who shall be oppressed by the White Dragon. ${ }^{52}$

The fact that Merlin so explicitly interprets this first prophecy is significant: it establishes as clearly as one can in the genre of prophetic interpretation that the ancient Britons will suffer defeat, displacement ("the white dragon will occupy its caves"), and extermination by foreign invaders of the island of Britain. ${ }^{53}$ If the $P M$ thus begins with the idea of British defeat (and the subsequent colonization of Britain by other peoples), it does little to reverse or even to mitigate the idea. Many, many prophecies follow - 15 pages of prose in the most recent edition of the Latin ${ }^{54}$ - but they provide few rallying cries for the Britons. At one point not far from the beginning of the $P M$, Geoffrey might seem to offer, however cryptically, a gleam of hope:

At that time there will be slaughter of the foreigners, and the rivers shall run with blood, and the mountains of Armorica will crumble, and they will don the crown of Brutus. Wales shall be filled with gladness, and the oaks of Cornwall will flourish. The island will be called by the name of Brutus and its foreign name will perish. ${ }^{55}$

This prophecy would promise a sort of "Celtic revival" involving Brittany, Cornwall, and Wales - all Brittonic nations - in the general resurgence, but, once one attempts to coordinate Merlin's prophecies with historical events, the difficulty in pinpointing exactly what series of events are being referenced here proves insurmountable. If one looks within the pages of Geoffrey's own history (and thus to the character Merlin's own future), the only possible moment of such native resurgence would be the reign of King Arthur, who did indeed extirpate the Saxons and restore legitimate British rule. Looking beyond the pages of the $D G B$ itself and up to the time of Geoffrey's writing, one again

$52 \quad D G B$, Prophetiae 112.34-36: "Vae rubeo draconi; nam exterminatio eius festinat. Cauernas ipsius occupabit albus draco, qui Saxones quos inuitasti significant. Rubeus uero gentem designat Britanniae, quae ab albo opprimetur."

$D G B$, Prophetiae 112.34-35: "cauernas ipsius occupabit albus draco."

$54 D G B$, Prophetiae $112-17$.

$55 D G B$, Prophetiae 115.111-14: "Tunc erit strages alienigenarum, tunc flumina sanguine manabunt, tunc erumpent Armorici montes et diademate Bruti coronabuntur. Replebitur Kambria laeticia, et robora Cornubiae uirescent. Nomine Bruti uocabitur insula, et nuncupatio extraneorum peribit." 
searches in vain for such a moment; even if Geoffrey is obliquely referencing here the Welsh rebellion of the 113os, the $P M$ disallows anything like an authoritative interpretation. Significantly, this brief prophecy of British resurgence is swiftly followed by many more vertiginous pages of even more covertly symbolic prophecies, culminating in the end not in the promise of a renewal of British fortunes but in a maelstrom of apocalyptic imagery drawn largely from the biblical books of Ezekiel, Isaiah, and Revelation.

Geoffrey of Monmouth acknowledged the popularity of his Merlinic prophecies, and he readily capitalized on this fame (or notoriety) in his composition in Latin hexameter verse of the $V M$ later in his career. Whereas the $D G B$ had featured Merlin as a boy speaking truth to power, a sort of Samuel to Vortigern's Saul, the $V M$ depicts him as an older, sadder, and perhaps wiser man. Driven temporarily insane by the outcome of a disastrous battle and estranged from his wife Guendolena, Merlin retreats to the depths of the forest of Calidon, seeking there a life of pastoral simplicity and astronomical study and all the while continuing to prophesy. He is eventually joined there by Taliesin, a figure (originally a historic 6th-century Welsh bard) about whom much disparate Welsh lore had aggregated and through whom Geoffrey stages a lengthy exposition of natural philosophy; by the madman Maeldinus, whom Merlin is able to restore to his right mind; and by Merlin's own sister Ganieda, to whom he passes his prophetic gift at the end of the poem. In the course of the poem, Merlin rehearses much of the narrative historical material found in books eight through ten of the $D G B$. In particular, Merlin provides further details of King Arthur's enigmatic death. Cognizant of the potential of Arthur both as a rallying-point for Welsh resistance to foreign rule and also as a paradigm of an expansionist Britain centered around Loegria (England), the VM keeps Arthur handily alive: the wounded king was rescued from the fateful Battle of Camlan and taken to the Insula Pomorum ("the Island of Apples" - certainly a gloss on the $D G B$ 's Avalon) to be healed of his wounds by the mysterious Morgen, the forerunner of the Morgan le Fay of the later Arthurian romances. Geoffrey has Merlin carefully emphasize that Arthur will have to remain with Morgen for a long but unspecified duration of time. ${ }^{56}$

The king's uncertain future mirrors in a way the uncertainty of the prophecies as a whole. By and large, the prophecies uttered by Merlin and Taliesin in the $V M$ do little to elucidate any of the specific predictions in the $P M$, and Geoffrey in fact employs many of the same rhetorical tricks: animal symbolism, astrological omens, and an often pointedly biblical diction. The Boar of Cornwall, the Sea Wolf, the Lion of Justice - all figures familiar from the $D G B$ 's 
version of the prophecies - return in the $V M$, and yet their referents are hardly made clearer, even if the $V M$ is somewhat more explicit about mentioning specific groups of peoples, such as the Gewissei, the Armoricans, and the Danes. However, if Galfridian prophecy in general aims at a studied ambiguity, the one moment where it departs from this mode is Ganieda's prophecy at the end of the $V M$. Her words are clear and difficult to misinterpret:

Leave, Normans, and stop your wanton armies from bearing their weapons through our homeland. There is nothing left now worth feeding your greed, for you have gobbled up everything that Mother Nature has long produced here in her marvelous fertility. Christ, aid Your people! Hold the Lions back! Restore the realm's tranquility and freedom from wars. ${ }^{57}$

On the one hand, such a passage, narrated as it is at the dramatic moment of Ganieda's assumption of the prophetic gift from her brother, articulates a clearly anti-Norman political message. And yet, couched as it is at the end of a series of dark and difficult prophetic utterances, and addressed as the $V M$ is to a patron (the bishop of Lincoln) thoroughly implicated in Norman power structures, one wonders whether Ganieda's, or Geoffrey's, speech-act can be held to be efficacious. The question - as Geoffrey no doubt intended - remains an open one.

It has thus become a critical commonplace to emphasize that the specific predictions in both the $P M$ and the $V M$ are obscure, probably deliberately so. ${ }^{58}$ While Merlin does interpret the omen of the two dragons for Vortigern (and for Geoffrey's readers) in the $D G B$, no key is given for any of the other prophecies; indeed, their sheer length alone would confound most attempts at systematic interpretation. For Echard, the increasing hermeneutic difficulty of the $P M$, taken in conjunction with its centrality to the narrative of the $D G B$ as a whole, reflects Geoffrey's sense of the fundamental directionlessness and unpredictability of history. ${ }^{59}$ Perhaps. But comparison with the analogues and potential sources of the $P M$ also reveals Geoffrey's preoccupation with the ways in which prophecy can make meaning of history and even make contemporary actions in the present meaningful.

$V M$, ll. 1511-17: "Iteque Neustrenses, cessate diutius arma / ferre per ingenuum violente milite regnum! / Non est unde gulam valeatis pascere vestram. / Consumpsistis enim quicquid natura creatrix / fertilitate bona dudum produxit in illa. / Christe, tuo populo fer opem, compesce leones, / da regno placidam bello cessante quietem!" (translation mine).

$5^{8} \quad$ Faletra, "Narrating the Matter of Britain", p. 75.

59 Echard, Arthurian Narrative, p. 59. 
Although no exact source has ever been identified for Geoffrey's version of the prophecies in either the $P M$ or the $V M$, it is clear that he was familiar with some of the Welsh traditions of political prophecy - a genre that dates back to at least the 1oth-century Welsh poem Armes Prydein Vawr ("The Great Prophecy of Britain") and that often employed the voice of the fictionalized poet-prophet Myrddin (whose name Geoffrey Latinized as Merlinus).$^{60}$ These Welsh Merlinic prophecies were virulently anti-Saxon and, as the tradition developed, also anti-Norman: the VM's dramatic gesturing about casting off the Norman yoke likely derives from the same or similar traditions. Although the Welsh prophecies do traffic in some difficult imagery (as well as in topical references we will likely never reconstruct), their overall political thrust was quite clear: they articulated an anti-colonialist fantasy in which the Welsh would rise up, slaughter all the foreigners in the land, and reconquer the entirety of the island of Britain for themselves. Any reader familiar with such prophecies would immediately recognize how different Geoffrey's are. In Geoffrey's version, the symbolism seems quite deliberately obscurantist, the political intent deeply unclear, and the only prophecy whose images seem even vaguely redolent of a resurgence by the ancient Britons (or the more contemporary Welsh or Bretons) is buried in the middle of a long series of other prophecies predicting a general period of civic unrest. In presenting his own version of the Merlinic prophecies, Geoffrey of Monmouth thus defuses much of the genre's anticolonial content while co-opting its rhetorical force to create what might well be, judging from the reception history of the $P M$, an elaborate parlor game for the Anglo-Norman intelligentsia. ${ }^{61}$ The $V M$ likewise affords the curious reader with little purchase in decoding its patterns of symbolism, even if it makes a few clearer references to the Arthurian and post-Arthurian worlds. In other words, Geoffrey himself might be said to be colonizing the Merlinic prophecy in the act of purporting to translate it and incorporating it into his own work.

The work of a contemporary Anglo-Latin writer, John of Cornwall ( $f .1155^{-}$ 76), brings the extent of Geoffrey's use of the native anti-English prophetic tradition into relief. ${ }^{62}$ John composed his own Latin translation of a set of

6o For an overview of the early Welsh prophetic tradition, see A.O.H. Jarman, "The Merlin Legend and the Welsh Tradition of Prophecy", in R. Bromwich, A.O.H. Jarman, and B.F. Roberts (eds.), The Arthur of the Welsh: The Arthurian Legend in Medieval Welsh Literature (Arthurian Literature in the Middle Ages, 1), Cardiff, 1991, pp. 117-46; and see also Armes Prydein Vawr, ed. and trans I. Williams and R. Bromwich, Armes Prydein: The Prophecy of Britain from the Book of Taliesin, Dublin, 1972.

$61 \quad$ Faletra, "Narrating the Matter of Britain", pp. 77 and 84, n. 63.

62 For the text of John of Cornwall's Prophetia Merlini, see M.J. Curley, "A New Edition of John of Cornwall's Prophetia Merlini", Speculum 57:2 (1982), 217-49. For a full discussion of 
Merlin's prophecies around $115^{\circ}-5^{2}$, most likely in response to the popularity of Geoffrey's version of the prophecies in the $D G B$. John's Prophecy of Merlin (Prophetia Merlini) is far briefer than Geoffrey's version, and far more to the point: John in fact provides it with a series of clarifying glosses. Indeed, even a cursory comparison demonstrates that, while John's prophecy shares many details of image and wording with Geoffrey's, its overall tone is closer to the political vehemence of the Welsh political poetry; John even evinces details drawn from that tradition - or, quite possibly, from a parallel tradition of political prophecy in Cornish. Most importantly, John of Cornwall does not dilute, delete, or obscure this political content but instead showcases it right up until his final line. The explanatory glosses he provides to his Prophecy, moreover, enable less erudite readers (and one wonders if there were ever any readers erudite enough to follow Geoffrey's $P M$ ) to make more authoritative connections with real-world events, through to the 12th century. In contrast, the widely varying commentaries on Geoffrey's version of the prophecies expose a fundamental hermeneutic confusion. John of Cornwall, in other words, may well supply some of the same elite Anglo-Latin audiences with the authoritative, relatively clear, and resolutely anti-colonialist Merlinic prophecy that Geoffrey did (and could) not.

If Geoffrey's $P M$ seems calculated to disable any easy or authoritative interpretation, the third and final prophetic moment in the $D G B$ offers a much more transparent stance on the meaning of British history and the place of the peoples of Britain therein. This third prophecy is directed to Cadualadrus, the unsuspecting last king of the Britons, by an angelic voice (uox angelica) - in contrast to the two earlier prophecies which were uttered by the pagan goddess Diana and the half-daemonic Merlin (son of an incubus and a nun), respectively - thus immediately lending it a far greater authority. The injunctions of this angelic voice are crystal clear:

While [King Cadualadrus] was preparing the fleet, the Angelic Voice rang out and commanded him to stop his undertaking. God did not want the Britons to rule in the island of Britain any longer, not until the time came that Merlin had prophesied to Arthur. The Voice commanded him to go to Pope Sergius in Rome to do penance and be counted among the blessed. It said that the Britons might once again win back the island on the merit of their faith when the destined day arrived; but that would not

the complex relationship between John of Cornwall and Geoffrey of Monmouth's respective versions of the $P M$, see M.A. Faletra, "Merlin in Cornwall: The Source and Contexts of John of Cornwall's Prophetia Merlini", JEGP 111:3 (2012), 303-38. 
happen until the Britons had brought Cadwallader's body back to Britain from Rome. Then, at long last, after the recovery of the relics of all the other saints as well, which they had hidden in the face of pagan invasion, they would regain their lost kingdom. ${ }^{63}$

The angel's voice is both a prophecy and not a prophecy: it issues statements about the future, it renders commands for the present, and it outlines conditions that need to be fulfilled. It claims both that the Britons will lose Britain (presumably to the Angles and Saxons who will rule the island for hundreds of years, as Geoffrey well knew), and that they might regain it one day. Like the previous two prophecies, this third one is also explicitly about the passage of dominion - about the transferal of Insular sovereignty - and thus also intimately linked with the colonial relations between the peoples of Britain (Welsh, Scots, Normans) in Geoffrey's own day. On the other hand, the angelic prophecy, despite its divine origin, is also surprisingly opaque, and it would seem to undercut any real use of it as a focal point for, say, a Welsh or panBrittonic insurgency against the 12th-century English. The Voice refers, for instance, to an alleged prophecy of Merlin to Arthur, an event that Geoffrey never narrates in the $D G B$, where, in fact, Merlin exits the stage after Arthur's conception. Moreover, the conditions tied to the recovery of all the lost saints' relics seem to be setting up a Herculean task, perhaps an impossible one. Add to this the fact that Geoffrey probably knew from at least some of his sources that King Cadwaladr actually died in Britain of the plague and not in Rome and that at least some of his readers may have known this story too - and it seems rather more likely that, in many aspects, the angel's prophecy of British restoration may be Geoffrey's way of saying "when Hell freezes over". Geoffrey, in other words, offers a prophecy of a native British insurgence against the island's foreign occupiers, who would certainly include his elite Anglo-Norman audiences, only to foreclose, or indefinitely forestall, the likelihood of its ever coming to fruition.

$63 D G B$, xi.205.563-73: "intonuit ei uox angelica dum classem pararet ut coeptis suis desisteret. Nolebat enim Deus Britones in insulam Britanniae diutius regnare antequam tempus illud uenisset quod Merlinus Arturo prophetauerat. Praecepit etiam illi ut Romam ad Sergium papam iret, ubi peracta paenitentia inter beatos annumeraretur. Dicebat etiam populum Britonum per meritum suae fidei insulam in futuro adepturum postquam fatale tempus superueniret; nec id tamen prius futurum quam Britones, reliquiis eius potiti, illas ex Roma in Britanniam asportarent; tunc demum, reuelatis etiam ceterorum sanctorum reliquiis quae propter paganorum inuasionem absconditae fuerant, amissum regnum recuperarent." 
Still, even in the end, Geoffrey prefers to hedge his bets, and both the $D G B$ and the $V M$ remain ambivalent at best, and sometimes even contradictory, in their thinking about colonizers and colonized, about a divinely-ordained translatio imperii, and about the claims of any people to Insular sovereignty. Geoffrey ends his book by showing the British fall into barbarity, and yet he also enables a possible future, however improbable and however distant, that would restore native control of Britain. He narrates a robust myth of Trojan origins for the ancient Britons and then undercuts it by positing a race of giants as Albion's real aboriginals. He glorifies the Welsh folk-hero Arthur and gives him an empire while also showing how this empire too crumbles to dust in the end. And in the $V M$ he revives his hallmark character only to have him cede his prophetic authority in the end to his equally enigmatic sister. All in all, we might say that Geoffrey is committed to expressing the playfulness, as Valerie Flint puts it, and the directionlessness, as Siân Echard puts it, of history itself.

And yet, despite the ludic energies bristling beneath the surface of the $D G B$, Geoffrey's work as a whole presents itself as a history, and was certainly understood as such, despite the occasional skeptic, for hundreds of years. Given the energy that the $D G B$ exerts in thinking through issues of colonization and native sovereignty, however, it seems that the text is hardly innocent of the realities of power in 12th-century Britain, a dynamic that Michelle Warren characterizes well:

When Geoffrey of Monmouth provided the master narrative of the Britons' imperial past, he gave them a history and thus an identity for the future. The gift (identity through history), however, remained the property of others and therefore contested territory. The writing and rewriting of Briton history thus creates and retrenches the boundary between those with and without their own past. ${ }^{64}$

The historiographical traditions that emerge from Geoffrey's $D G B$ bear witness to the text's rich capacity to serve as an instrument of power for both colonizers and colonized. Translated into both French (Wace, Gaimar) and Middle English (Lazamon), the contents of the $D G B$ passed rapidly into mainstream English chronicle tradition, engendering a host of Prose Bruts and even being taken up by such serious later historians as Matthew Paris and Ranulph Higden. Typically, the medieval English regarded Geoffrey's account of the British past valuable primarily because it provided a pre-history that seemed in the main to smooth the way to a comfortable English hegemony and because it supplied

64 Warren, History on the Edge, p. 11. 
several exemplary figures - conveniently sanitized of any ethnic (i.e. Welsh) origins - to claim as part of their own past, especially King Arthur. On the other hand, Geoffrey's history also found its way to Wales, where it was quickly adapted to Welsh political concerns in the robust Welsh chronicle traditions of Brut y Brenhinedd ("History of the Kings") and Brut y Tywysogyon ("History of the Princes"), the former a loose translation of the $D G B$ and the latter explicitly conceived as a continuation of Galfridian history in the present. Indeed, the First Variant Version of the $D G B$ was plausibly composed in Wales, and it interestingly mitigates much of Geoffrey's more objectionable content, such as his discussion of Welsh barbarity. The variety of responses to Geoffrey's project may well bear witness to the pseudo-history's success at not overcommitting itself to any particular political position, but it also demonstrates the lasting appeal of Geoffrey's preoccupation with the way colonization and conquest form a vital element of the weft and warp of any account of the past, even a largely fictitious one. 